Огляди літератури, оригінальні дослідження, погляд на проблему, випадок з практики, короткі повідомлення УДК 616.12-005.8-06:616.12-008.331.1-06:616.379-008.64

DOI 10.11603/1811-2471.2021.v.i3.12525

\title{
ВПЛИВ ЦИТОПРОТЕКТОРНОÏ ТЕРАПІЇ НА ДВОРІЧНЕ ВИЖИВАННЯ ХВОРИХ ІЗ ГОСТРИМ ІНФАРКТОМ МІОКАРДА ТА КОМОРБІДНОЮ ПАТОЛОГІЕЮ
}

\author{
๑В. Р. Микуляк, М. В. Гребеник, Л. І. Зелененька, Л. В. Зоря \\ Тернопільський національний медичний університет імені І. Я. Горбачевського МОз України
}

РЕЗЮМЕ. Оптимізація методів лікування гострого інфаркту міокарда в умовах коморбідності $\epsilon$ одним із актуальних напрямків сучасної медицини. Реалізація даного завдання можлива за рахунок додаткового до стандартної терапії використання препаратів цитопротекторної дії (кверцетин, L-аргінін) у гострому періоді інфаркту міокарда, що підтверджується аналізом показників дворічного виживання хворих, включених у дослідження.

Мета - оцінка віддалених результатів виживання хворих на інфаркт міокарда з коморбідною патологією, яким у гострому періоді додатково до стандартної терапії призначали препарати цитопротекторної дії.

Матеріал і методи. Обстежено 506 пацієнтів, які перебували на стаціонарному лікуванні в Тернопільському міському кардіологічному центрі. Пацієнти були поділені на групи залежно від коморбідної патології. Групи були рандомізовані на підгрупи залежно від схеми лікування у гострий період інфаркту міокарда. Аналіз віддаленого виживання хворих було проведено за методикою Kaplan - Meier, різниця показників оцінювалась за допомогою логарифмічного рангового критерію $\left(\chi^{2}\right)$.

Результати. Виживання упродовж 2 років після інфаркту міокарда виявилось найкращим у пацієнтів, які в гострий період отримували додатково до стандартної терапії L-аргінін. Показники виживання за даними логарифмічного рангового критерію достовірно відрізнялись $\left(\chi^{2}=12,120 ; p=0,001\right)$ від групи пацієнтів, які отримували лише стандартну терапію. Кумулятивна частка виживання для пацієнтів, які додатково отримували цитопротекторну терапію (L-аргінін або корвітин) теж достовірно відрізнялась від осіб, що отримували виключно терапію згідно з протоколом $\left(\chi^{2}=14,281 ; p=0,001\right)$.

Висновки. Результати дворічного спостереження засвідчили покращення виживання хворих із коморбідною патологією у віддаленому післяінфарктному періоді при використанні у гострому періоді інфаркту міокарда цитопротекторної терапії, зокрема L-аргініну та кверцетину.

КЛючОВІ СЛОВА: гострий інфаркт міокарда; коморбідність; цитопротекторна терапія; виживання.

Вступ. Гострі форми ішемічної хвороби серця (IXC) посідають провідне місце в загальній структурі серцево-судинної захворюваності та смертності [1]. Щорічно в Україні реєструється понад 40000 випадків інфаркту міокарда (IM), і незважаючи на суттєві досягнення інтервенційної кардіології, використання фармакоінвазивних технологій, летальність становить близько 20 \% [2]. На думку багатьох науковців, однією із причин несприятливих тенденцій $\epsilon$ значна поширеність коморбідності у популяції $[3,4]$. За результатами досліджень D. Campbell-Scherer [5], поширеність коморбідних станів коливається від 69 \% у хворих молодого віку до 93 \% у пацієнтів середнього віку і сягає $98 \%$ у пацієнтів похилого віку.

Тому удосконалення методів лікування гострого ІМ в умовах коморбідності $\epsilon$ одним із найактуальніших напрямків сучасної медицини. Нещодавні клінічні дослідження $[6,7]$ показали, що реалізація цього завдання можлива за рахунок використання додатково до стандартної терапії препаратів цитопротекторної дії у гострому періоді ІМ. Зокрема, особливий інтерес викликають біофлавоноїд кверцетин та донатор оксиду азоту L-аргінін, які мають мембранопротекторні, антиоксидантні властивості та здатність покращувати функцію ендотелію $[8,9]$. Використання вказаних препаратів у гострому періоді IM сприяє знижен- ню частоти ускладнень госпітального періоду, зумовлює швидшу позитивну динаміку електрокардіограми та зменшення проявів патологічного ремоделювання міокарда у віддаленому післяінфарктному періоді, тим самим запобігаючи розвитку тяжкої серцевої недостатності, що впливає на виживання хворих $[10,11]$.

Мета - оцінка віддалених результатів виживання хворих на IM з коморбідною патологією, яким у гострому періоді додатково до стандартної терапії призначали препарати цитопротекторної дії.

Матеріал і методи дослідження. 3 локального реєстру було відібрано 506 пацієнтів, які перебували на стаціонарному лікуванні в Тернопільському міському кардіологічному центрі. Проведено клініко-лабораторні, інструментальні обстеження та верифіковано діагноз ГКС з елевацією/ без елевації сегмента ST, згідно з рекомендаціями ESC, 2017. Пацієнти були поділені на групи залежно від коморбідної патології. Перша (1 гр.) - хворі на IM із супутньою артеріальною гіпертензією (АГ) і цукровим діабетом (ЦД) ( $=118)$, середній вік яких склав $(66,59 \pm 0,96)$ років, друга (2 гр.) - хворі на IM із супутньою АГ без ЦД ( $n=285)$, середній вік яких становив $(64,94 \pm 0,72)$ років, третя (3 гр.) - хворі на IM без супутньої патології (n=103), середній вік яких був $(60,35 \pm 1,42)$ років. Групи були рандомі- 
Огляди літератури, оригінальні дослідження, погляд на проблему, випадок з практики, короткі повідомлення зовані на підгрупи залежно від схеми лікування: підгрупа «с» - хворі отримували стандартну терапію ІМ згідно з чинним протоколом МОЗ України. Підгрупа «а» - додатково до стандартної терапії призначали L-аргінін (Тівортін, «Юрія-Фарм», Україна): впродовж 5 днів проводилось внутрішньовенне введення 100 мл 4,2 \% розчину L-аргініну гідрохлориду (доза 4,2 г) один раз на день, з наступним переходом на пероральний прийом L-аргініну acпартату у дозі 6 г на добу до виписування зі стаціонару (14-16 діб). Підгрупа «К» - додатково до стандартної терапії призначали водорозчинну форму кверцетину (Корвітин, ЗАТ НВЦ "Борщагівський ХФЗ», Україна). Використовували схему, рекомендовану при гострому IM: 0,5 г 10 \% препарату, розчиненого в 50 мл фізіологічного розчину натрію хлориду, шляхом внутрішньовенної інфузії протягом 20 хвилин вводили зразу після госпіталізації хворого з ІМ. Потім інфузію повторювали через 2 та 12 годин у такій самій дозі. На 2 та 3 добу корвітин вводили двічі по 0,5 г з інтервалом 12 годин, на 4 та 5 добу-однократно в дозі 0,25 г.

Період спостереження склав 2 роки. Аналіз віддаленого виживання хворих було проведено за методикою Kaplan - Meier, різницю показників оцінювали за допомогою логарифмічного рангового критерію $\left(\chi^{2}\right)$.

Статистичну обробку результатів проводили після внесення даних у електронні таблиці Microsoft Excel $(7,0)$. Опрацювання даних виконували за допомогою ліцензованих пакетів програмного забезпечення: Statistica ${ }^{\circledR}$ Version 6.0 (StatSoft, Inc., США) та SPSS ${ }^{\circledR}$ V. 21.0 Standart Version (SPSS Inc.).

Результати й обговорення. Аналіз даних локального реєстру, до якого було включено 506 випадків гострого IM міського кардіологічного центру, підтвердив тенденцію до зростання частки коморбідності у популяції. Супутню патологію виявлено у 88,5 \% хворих на гострий IM. Наявність одного захворювання в анамнезі виявлено у $54,8 \%$ хворих, двох і більше -у $33,7 \%$, не виявлено супутньої патології лише у 11,5 \% обстежених хворих.

У нашому дослідженні найчастіше IM супроводжувала АГ - 77,5 \%, що цілком збігається з даними Українського реєстру гострого ІМ. Судинна патологія в структурі коморбідності склала $22,3 \%$. Серед цих пацієнтів найбільший відсоток становили особи з перенесеним інсультом, транзиторними ішемічними атаками, облітеруючим атеросклерозом нижніх кінцівок. ЦД 2-го типу виявлено у $22,9 \%$ хворих на IM, що також відповідає даним реєстру IM.

Проаналізовано дворічне виживання пацієнтів, які були включені у дослідження. Серед останніх за час спостереження від патології серцево-судинної системи померло 86 осіб (17,0%). Найвищою віддалена смертність виявилась у хворих на IM із супутньою АГ і ЦД. Померло 24 пацієнти, що склало 20,3 \%. У групі хворих на ІМ із супутньою АГ впродовж 2 років померло 48 осіб (16,8\%). Найнижча віддалена летальність (13,6 \%) спостерігалась у хворих на IM без супутньої патології, померло 14 осіб. Отже, коморбідність у хворих на гострий IM істотно впливає на показник виживання.

Результати дослідження продемонстрували зменшення летальності у групі хворих, яким застосовували фармакоінвазивні методи лікування та раннє черезшкірне коронарне втручання, $p<0,001$. Летальність обернено корелювала з фармакоінвазивними методиками $(r=-0,152, p=0,001)$ та черезшкірними коронарними втручаннями ( $r=-0,167$, $p<0,0001)$.

Підтверджений позитивний вплив фармакологічних засобів на зниження летальності та дворічної смертності хворих на ІМ у гострий та віддалений періоди: статинів $(r=-0,380, p=0,0001)$, аспірину $(r=-0,145, p=0,001)$, тієнопіридинів $(r=-0,123$, $p=0,005), \beta$-адреноблокаторів $(r=-0,333, p=0,0001)$, ІАПФ/БРА ( $r=-0,338, p=0,0001)$.

Основним завданням дослідження було простежити віддалене виживання хворих, яким у гострий період IM додатково призначали препарати L-аргінін та корвітин. Аналіз віддаленої смертності показав, що через півроку після перенесеного ІМ померло 14,3 \% пацієнтів, включених у дослідження, а смертність упродовж 1-го року сягнула - 16,2 \%. У цілому, впродовж дворічного терміну спостереження за даною популяцією хворих, які перенесли IM, померло 36 осіб, що склало $17,1 \%$.

Аналіз виживання по підгрупах було проведено за методикою Kaplan-Meier (рис. 1), різниця показників оцінювалась за допомогою логарифмічного рангового критерію $\left(\chi^{2}\right)$. Статистичний аналіз показників виживання підгруп лікування представлено у таблиці 1.

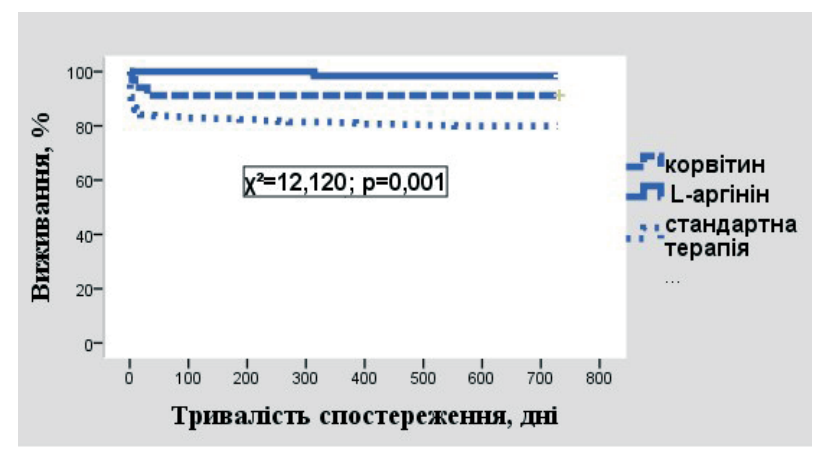

Рис. 1. Дворічне виживання хворих залежно від схеми лікування у гострий період інфаркту міокарда. 
Огляди літератури, оригінальні дослідження, погляд на проблему, випадок з практики, короткі повідомлення Таблиця 1. Логарифмічний ранговий критерій різниці виживання у підгрупах лікування

\begin{tabular}{|l|c|c|}
\hline \multicolumn{1}{|c|}{ Підгрупа лікування } & $\chi^{2}$ & $\mathrm{P}$ \\
\hline Стандартна терапія +L-аргінін, стандартна терапія + корвітин, стандартна терапія & 14,281 & 0,001 \\
\hline Стандартна терапія +L-аргінін / стандартна терапія & 12,120 & 0,001 \\
\hline Стандартна терапія +корвітин / стандартна терапія & 2,487 & 0,115 \\
\hline Стандартна терапія +L-аргінін / стандартна терапія + корвітин & 2,993 & 0,842 \\
\hline
\end{tabular}

Як видно з рисунка 1 і даних, представлених у таблиці 1, найкраще виживання упродовж 2 років після ІМ виявилось у пацієнтів, які в гострий період отримували додатково до стандартної терапії L-аргінін. Показники виживання за даними логарифмічного рангового критерію достовірно відрізнялись від групи пацієнтів, які отримували лише стандартну терапію. Кумулятивна частка виживання для пацієнтів, які додатково отримували метаболічну терапію (L-аргінін або корвітин), теж достовірно відрізнялась від осіб, що отримували виключно терапію згідно з протоколом.

\section{ЛITЕРАТУРА}

1. Серцево-судинні захворювання. Класифікація, стандарти діагностики та лікування / В. М. Коваленко, М. І. Лутай, Ю. М. Сіренко, О. С. Сичов, - 4-те вид., переробл. і доповн. - Київ: МОРІОН, 2020. - 240 с.

2. Клініко-анамнестична характеристика та перебіг госпітального періоду захворювання у хворих молодого віку з гострим коронарним синдромом з елевацією сегмента ST / О. М. Пархоменко, Я. М. Лутай, О. І. Іркін [та ін.] // Укр. кардіол. журнал. - 2018. - №4. - С. 31-39.

3. Коморбідність: визначення, можливі напрямки діагностики та лікування / В. М. Коваленко, О. П. Борткевич // Український ревматологічний журнал. - 2019. № 3. - С. 33-44.

4. Association of comorbidities with clinical outcomes in patients after acute myocardial infarction / C. Baechlia, D. Kocha, S. Berneta [et al.] // IJC Heart \& Vasculature. 2020. - Vol. 29. - P. 550-558.

5. Prevalence and impact of non-cardiovascular comorbidities among older adults hospitalized for non-ST segment elevation acute coronary syndrome / R. Ofori-Asenso, E. Zomer, K. L. Chin [et al.] // Cardiovasc. Diagn. Ther. 2019. - Vol. 9. - P. 250-261.

6. Батушкін В. В. Цитопротекція при гострому інфаркті міокарда після відкриття інфаркт-залежної артерії: нові горизонти / В. В. Батушкін // Ліки України (Medicine of Ukraine). - 2017. - № 8 (214). - C. 33-40.
Висновки. Результати дворічного спостереження засвідчили покращення виживання хворих із коморбідною патологією у віддаленому післяінфарктному періоді при використанні у гострому періоді інфаркту міокарда цитопротекторної терапії, зокрема L-аргініну та кверцетину.

Перспективи подальших досліджень. Подальша оцінка клініко-функціональної ефективності L-аргініну та кверцетину у віддаленому післяінфарктному періоді, а саме їх вплив на ремоделювання міокарда.
7. Роль метаболической терапии в современной кардиологии / В. В. Резван, И. С. Васильева // РМЖ. 2016. - № 19. - С. 1276-1280.

8. Особливості застосування метаболічної терапії у хворих на гостру та хронічну ішемічну хворобу серця: аналіз цифрової обробки електрокардіограми за допомогою програмного комплексу «Смарт-ЕКГ» / В. К. Тащук, П. Р. Іванчук, О. С. Полянська [та ін.] // Клінічна та експериментальна патологія. - 2018. - № 17 (2). С. 99-106.

9. Роль L-аргініну в лікуванні серцево-судинних захворювань: у фокусі - вибір ефективної дози / О. В. Курята, М. М. Гречаник // Здоров'я України. - 2019. № 11 (456). - С. 17-18.

10. Кількісна оцінка електрокардіограми в порівнянні ефективності кардіопротекції при гострому інфаркті міокарда / В. К. Тащук, П. Р. Іванчук, М. В. Тащук [та ін.] // Буковинський медичний вісник. - 2017. № 21. - С. 94-99.

11. Шляхи підвищення ефективності лікування та профілактики реперфузійного синдрому у хворих на гострий коронарний синдром (інфаркт міокарда), яким проведено балонну ангіопластику та стентування коронарної артерії / М. І. Швед, Л. В. Цуглевич, С. М. Геряк [та ін.] // Здобутки клінічної і експерементальної медицини. - 2019. - № 1. - С. 173-181. 
Огляди літератури, оригінальні дослідження, погляд на проблему, випадок з практики, короткі повідомлення REFERENCES

1. Kovalenko, V.M., \& Lutaj, M.I. (2020). Sercevo-sudynni zahvoryuvanja. Clasifikacija, standarty diagnostyky ta likuvanja [Cardiovascular desease. Classification, standards of diagnosis and treatment]. Kyiv: Morion [in Ukrainian].

2. Parxomenko, A.N., Lutaj, Ya.M., Irkin, O.I., Bilyi, D. O., Stepura, A. O., Kushnir, S.P., Skarzhevskyi, O.A., \& Shumakov, O.V. (2018). Kliniko-anamnestychna kharakteristyka i perebig hospitalnoho periodu zakhvoriuvannia u hvoryh molodoho viku z hostrym koronarnym syndromom z elevaciieiu sehmenta ST [Clinical, anamnestic characteristics and course of in-hospital period in young patients with ST-elevation acute coronary syndrome]. Ukrainskij Kardiologichnij Zhurnal - Ukrainian Journal of Cardilogy, 4, 31-39 [in Ukrainian].

3. Kovalenko, V.M., \& Bortkevych O.P. (2019). Komorbidnist: vyznachennja, mozhlyvi naprjamky diagnostyky ta likuvannja [Comorbidity: Definition, possible ways to diagnostics and treatment]. Ukrainskij Revmatologichnij Zhurnal Ukrainian Journal of Rheumatology, 3, 33-44 [in Ukrainian].

4. Baechlia, C., Kocha, D., Berneta, S., Gut , L., Wagner, U., Mueller, B., Schuetz, Ph., \& Kutz, A. (2020) Association of comorbidities with clinical outcomes in patients after acute myocardial infarction. IJC Heart \& Vasculature, 29, 550-558.

5. Ofori-Asenso, R., Zomer, E., Chin, K.L., Si, P. Markey S., Ademi, Z., Curtis, A. J., Zoungas, S., \& Liew, D. (2019). Prevalence and impact of non-cardiovascular comorbidities among older adults hospitalized for non-ST segment elevation acute coronary syndrome. Cardiovasc. Diagn. Ther., 9, 250-261.

6. Batushkin, V.V. (2017). Tsytoprotektsiia pry hostromu infarkti miokarda pislia vidkryttia infarkt-zalezhnoi arterii: novi horyzonty [Cytoprotection in acute myocardial infarction after the discovery of a heart attack-dependent artery: new horizons]. Liky Ukrainy - Medicine of Ukraine, 8 (214), 33-40 [in Ukrainian].

7. Rezvan, V.V., \& Vasiljeva, I.S. (2016). Rol metabolicheskoy terapiji v sovremennoy kardiologiji [Role metabolic

treatment at modern cardiology]. Ryskij Medizindkij Zhurnal - Russian Medical Journal, 19, 1276-1280 [in Russian].

8. Taschuk, V.K., Ivanchuk, P.R., Polianska, O.S., Taschuk, K.H., \& Savchuk, O.V. (2018). Osoblyvosti zastosuvannia metabolichnoi terapii u khvorykh na hostru ta khronichnu ishemichnu khvorobu sertsia: analiz tsyfrovoi obrobky elektrokardiohramy za dopomohoiu prohramnoho kompleksu "Smart-ECG». [Peculiarities of the metabolic therapy use in patients with acute and chronic ischemic heart disease: analysis of digital processing of electrocardiogram]. Klinichna ta eksperymental'na patolohiia - Clinical \& experimental pathology, 17(2), 99-106 [in Ukrainian].

9. Kuriata, O.V., \& Hrechanyk M.M. (2019). Rol L-argininu v likuvannji sercevo-sudynnyh zahvoryuvan: u fokusi-vybir efektyvnoj dozy [Role L-arginin at the treatment of cardiovascular deseases: in the focus is selection of the optimal dose]. Zdorovja Ukrainy - Health of Ukraine, № 11 (456), 17-18 [in Ukrainian].

10. Taschuk, V.K., Ivanchuk, P.R., Taschuk, M.V., Polianska, O.S., Amelina, T.M., Makoviichuk, I.O., Onofreychuk, D.I., \& Shevchuk V.A. (2017). Kilkisna otsinka elektrokardiohramy v porivnyanni efektyvnosti kardioprotektsiyi pry hostromu infarkti miokarda [Quantitative evaluation of electrocardiogram in comparison of cardioprotection efficiency in acute myocardial infarction]. Bukovynskyi medychnyi visnyk - Bukovinian Medical Herald, 21, 94-99 [in Ukrainian].

11. Shved, M.I., Tsuglevich, L.V., Heryak, S.M., Kovbasa, N.M., Prokopovich, O.O., \& Jastremska, O.I. (2019). Shliakhy pidvyshchennia efektyvnosti likuvannia ta profilaktyky reperfuziinoho syndromu u khvorykh na hostryi koronarnyi syndrom (infarkt miokarda), yakym provedeno balonnu anhioplastyku ta stentuvannia koronarnoi arterii [Ways for improvement of central and peripheral hemodynamics in patients with acute coronary syndrome (myocardial infarction), who underwent balloon angioplasty and stenting of the coronary artery]. Zdobutky klinichnoi $i$ eksperementalnoi medytsyny - Achievements of Clinical and Experimental Medicine, 1, 173-181 [in Ukrainian].

\title{
THE INFLUENCE OF CYTOPROTECTIVE THERAPY ON 2-YEAR SURVIVAL OF PATIENTS WITH ACUTE MYOCARDIAL INFARCTION AND COMORBID PATHOLOGY
}

\author{
@V. R. Mykuliak, M. V. Hrebenyk, L. I. Zelenenka, L. V. Zoria \\ I. Horbachevsky Ternopil National Medical University
}

SUMMARY. Optimisation of therapeutic strategies for acute myocardial infarction in case of comorbidity is considered to be one of the actual directions of modern medicine. The implementation of this task is possible by the additional to standart treatment administration of cytoprotective therapy (quercetin, L-arginine) in the acute period of myocardial infarction, which is confirmed by analysis of 2-year survival of patients included in the study.

The aim - evaluation of long-term survival of patients with myocardial infarction and comorbid pathology, who were prescribed cytoprotective therapy in acute period additionally to standard protocol treatment.

Material and Methods. 506 patients with acute myocardial infarction admitted to Ternopil cardiology center were examined. Patients were divided into groups according to comorbid pathology. The groups were randomized into subgroups depending on the treatment performed in the acute period of myocardial infarction. The analysis of long-term survival of patients was performed according to the Kaplan-Meier method, the difference was assessed using the logrank test $\left(\chi^{2}\right)$. 
Огляди літератури, оригінальні дослідження, погляд на проблему, випадок з практики, короткі повідомлення

Results. The investigation showed better survival of patients after myocardial infarction who received L-arginine additionally to standard therapy in acute period. Survival rates according to the log rank test differed significantly $\left(\chi^{2}=2.20 ; p=0.001\right)$ from the group of basic therapy. The cumulative survival rate for patients receiving additional cytoprotective therapy (L-arginine or corvitin) also differed significantly from group receiving only protocol-based standard therapy $\left(\chi^{2}=14.28 ; p=0.001\right)$.

Conclusions. The results of a 2-year follow-up showed an improvement of long term survival of patients with myocardial infarction and comorbid pathology in distant postinfarction period who recieved cytoprotective therapy (L-arginine and quercetin) during the acute phase of disease.

KEY WORDS: myocardial infarction; comorbidity; cytoprotective therapy; survival. 